\title{
Genetic Characterization for Human Enterovirus Isolated from Busan Region in Korea
}

\author{
Nam-Ho Kim*, Sang-kee Min, Eun-hee Park, Yon-Koung Park, Sun-Mok Kwan and Seong-Hyeon Jin \\ Busan metropolitan City Institute of Health and Environment, Busan 613-806, Korea \\ Received March 3, 2010 / Accepted March 30, 2010
}

\begin{abstract}
Human enteroviruses (HEV) are considered one of the major infectious causes of central nervous system infections such as aseptic encephalomeningitis in pediatrics. This study was focused on providing information related to genetic characteristics and diversities of HEV which prevailed between 2007 and 2009 in Busan, Korea. A total of 2,743 specimens were collected from children and screened for isolation of HEV by cell culture and RT-PCR. Among the specimins, 240 isolates were grouped into 21 different HEV serotypes using VP1 RT-PCR. The major etiological agents were CV-A6 and CV-B2 in 2007, E-6 and E-30 in 2008 and CV-B1 in 2009. The occurrence of HEV infections was the most frequent in the summer (May to August, 188 cases, 78.3\%). Most of the isolates were identified from specimens from children under 10 years old, with the highest occurrence in the 2 to 4 year old range $(15.2 \%)$. However, there were no significant differences between male and female children for the isolates. For analyzing genetic characterization, VP1 gene was amplified by RT-PCR and sequenced. The phylogenetic tree was established by Clustal W method using DNASTAR software. Using the sequence analysis of the VP1 region, it was classified into 2 groups; HEV-A and HEV-B. The HEV-A group contained 6 serotypes and sequences of 31 isolates were compared within each serotype. The HEV-B group contained 10 serotypes and the sequences of 41 isolates were compared within each serotype. Homology analysis of the VP1 region showed that the identity scores of HEV-A and B isolates were different. In conclusion, genetic divergences were observed among the isolates from children between 2007 and 2009 in Busan.
\end{abstract}

Key words : Busan, human enteroviruses (HEV), phylogenetic tree, RT-PCR, serotype

\section{서 론}

엔테로바이러스(human enteroviruses, HEV)는 Picornaviridae 과에 속하는 바이러스로, 3가지 혈청형의 Poliovirus와 23가지 혈청형의 Coxsackievirus A (CV-A)군, 6가지 혈청형의 Coxsackievirus B (CV-B)군, 그리고 8가지 혈청형의 Echovirus (E)군 및 Human enterovirus (EV-68 73) 등으로 구성되어 있 다[2,22]. 최근 연구자들은 reverse transcription - polymerase chain reaction (RT-PCR)에 의한 증폭된 염기서열의 분석을 통하여 3가지 혈청형의 Poliovirus (PV) 및 $\mathrm{HEV} \mathrm{A} \mathrm{D의} \mathrm{5가지}$ 유전자형으로 분류하기도 한다. HEV-A에는 CA-A2 A8, CV-A10, CV-A12, CV-A14, CV-A16, EV-71이 속하며, HEV-B 에는 CV-A9, CV-B1 6, E-1 7, E-9, E-11 21, E-24 27, $\mathrm{E}-29$ 33, EV-69, EV-73이 속하며, HEV-C에는 CV-A1, CV-A11, CV-A13, CV-A15, CV-A17 22, CV-A24가 속하며, 마 지막으로 HEV-D에는 EV-68, EV-70이 속한다[7,14]. 현재 이미 알려진 70 여종의 $\mathrm{HEV}$ 혈청형 이외에도 90 개 이상의 새로운 혈청형의 HEV가 동정되고 있으며[13], E-9의 유전자 재조합

\footnotetext{
*Corresponding author

Tel : +82-51-757-6936, Fax : +82-51-753-1424

E-mail : brave1210@korea.kr
}

에서부터[1] 타이완에서는 1998-2001년과 2002-2005년 검출된 EV-71에 유전자 재조합이 보고되고 있다[8]. 엔테로바이러스 의 유전자는 약 7.2 7.5 kb 크기의 single stranded positive sense RNA의 형태로[7], 캡시드는 12개의 pentamer로 구성되 어 있으며, 각각의 pentamer는 VP1, VP2, VP3, VP4 등 네 가지의 polypeptide로 이루어진 5개의 protomer로 구성되어 있다[21]. 바이러스의 유전자 중 한 부분을 차지하는 VP1 region은 $\mathrm{HEV}$ 동정에 우수한 유전적 상관관계가 있어 genotyping에 이상적인 target 부분으로 사용되며, 주요 항원 부위의 중화 결정자로서의 기능을 한다[12,16].

$\mathrm{HEV}$ 는 분변에 의해 오염된 강, 양식장 등의 수계에서 검출 된다는 보고가 있다[23]. HEV가 오랫동안 수계에서 축적되어 문제가 되는 것은 이러한 수계가 바이러스의 숙주로서 역할을 하여서이다[5]. 그 예로 매년 미국에서 발생하는 수인성 식품 매개 질환들에 식중독 유발 바이러스인 노로바이러스 이외에 $\mathrm{HEV}$ 의 검출이 보고되고 있다[26]. $\mathrm{HEV}$ 는 전세계적으로 퍼져 있고 분변-구강 경로를 통하여 사람에게 전파되며[15], 감염 후 일차적으로 소장의 림프절에서 증식한 후 각 장기로 이동 하게 된다[9]. 위장관내에서 존재하고 있는 $\mathrm{HEV}$ 는 무증상일 수도 있고[11], 질병을 유발할 수도 있다[25]. EV-71에 의한 폐 수종이나 뇌질환 합병증으로 사망하는 경우도 보고되고 있으 
며[6], 1997년 말레이시아, 1999년 호주, 2000년 싱가포르, 1997 년과 2000년 일본 등을 포함하는 서태평양지역 나라들에서 심각한 뇌질환과 관련 있는 EV-71의 집단발병 사례들이 보고 되고 있다[24]. 면역체계가 완벽하게 발달되지 않은 5세미만의 소아의 경우 $\mathrm{HEV}$ 는 중추신경계 감염의 가장 중요한 요인 중 의 하나로 인식되고 있다[20]. HEV 배양에 이용되는 세포주는 특이한 세포 수용기를 갖고 있으며, 바이러스 종류에 따라 세 포주에 대한 감수성 다르다[9]. 최근에는 $\mathrm{HEV}$ 의 유전자를 직 접 검출하는 RT-PCR법이 개발되어 환자로부터 채취한 검체 에서 바이러스의 존재 유무를 신속하게 분석할 수 있게 되었 다[4]. 본 실험에서는 세포배양과 RT-PCR을 이용해 확인하였 다. 부산지역의 $\mathrm{HEV}$ 데이터는 거의 없는 실정이며, 최근 중국, 아시아 등지에서 문제되고 있는 EV-71의 유행에 따른 국내유 입에 대한 우려 또한 간과할 수 없다. 그러므로 $\mathrm{HEV}$ 에 대한 감시체계의 확립과 유전학적 데이터를 축적하는 것은 매우 중요한 일이라 할 수 있다. 이에 본 연구의 목적은 최근 3년간 부산지역에서 분리된 $\mathrm{HEV}$ 를 대상으로 계통학적 분석을 통하 여 부산지역에서 유행하고 있는 $\mathrm{HEV}$ 의 유전적 다양성을 확인 하고, 그들의 염기서열에 대한 데이터베이스 구축을 위한 기 초 자료로써 제공하고자 하였으며 이를 통하여 $\mathrm{HEV}$ 에 대한 신 - 변종 바이러스 출현 및 독성이 강한 엔테로바이러스의 국내 유입에 대한 기준을 제시하고, 향후 새로운 진단법 개발 및 백신제 개발에 대한 기초 자료로써 제공하고자 한다.

\section{재료 및 방법}

\section{연구재료}

2007년부터 2009년까지 3년 동안 부산지역 병원에 수족구 병이나 (뇌)수막염으로 내원한 환자의 대변, 뇌척수액, 인후도 찰물 총 2,743 건을 검체로 사용하였다. 분변의 경우 $10 \%$ 의 chloroform (Merck, Germany)을 처리한 $\mathrm{pH}$ 7.4의 phosphate buffered saline (PBS, Sigma, USA) 용액에 분변 $2 \mathrm{~g}$ 넣고 20 분 동안 강하게 진탕한 후 $3,000 \mathrm{rpm}$ (UNION 32R PLUS, Hanil, Korea), $4^{\circ} \mathrm{C}$ 에서 20 분간 원심분리한 후 상층액을 사용하 였으며, 뇌척수액과 인후도찰물은 전처리 없이 본 실험에 사용 하였다.

\section{세포 배양}

국립보건원 간염 - 폴리오바이러스과로부터 분양받은 human rhabdomyosarcoma (RD), human larynx epidermoid carcinoma (Hep-2)와 African green monkey kidney cell (Vero), buffalo green monkey kidney cell (BGM) 세포주를 사용하였으며 각 세포들을 DMEM (GIBCO modified eagle medium, Invitrogen, USA)에 penicillin-streptomycin (Sigma, $\mathrm{USA}$ )을 첨가하여 $37^{\circ} \mathrm{C}, \mathrm{CO}_{2}$ 항온배양기(MCO-18AIC, SANYO, Japan)에서 배양하였다. $56^{\circ} \mathrm{C}$ 에서 30 분간 불활성화 시킨 $\mathrm{FBS}$ (GIBCO fetal bovine serum, Invitrogen, USA) 5\%를 첨가한 배양액을 이용하여 24 well plate (Multidish 24wells, Corning, $\mathrm{USA}$ )에 각각의 세포를 $2 \times 10^{4}$ cells/well로 24 시간 단층배양 한 후, 세포의 밀도가 약 $70 \%$ 정도 되었을 때 각각의 검체를 접종하였다. 세포배양액을 걷어낸 후에 PBS를 이용하여 세포를 세척하였으며 $2 \%$ 의 FBS가 포함된 배양액을 추가한 후 $100 \mathrm{ul}$ 의 검체를 접종하였다. 2 주일까지 도립 현미경(Axiovert $40 \mathrm{CFL}$, Carl Zeiss, Germany)을 이용하여 세포병변효과 (cytopathic effect; $\mathrm{CPE}$ )를 관찰한 후에 약 $70 \%$ 의 세포병변이 관찰되었을 때에 초저온냉동고 $\left(-70^{\circ} \mathrm{C}\right.$ freezer, Nihon freezer, Japan)에서 냉동시키고 다시 용해하는 과정을 반복한 후 현탁액을 세포에 재접종하여 바이러스를 분리하였다.

\section{RT-PCR of VP1 region}

검체 및 배양액 $200 \mathrm{ul}$ 을 ZR Viral RNA Kit (ZYMO Research, USA)를 이용하여 RNA를 추출하였으며, VP1 region의 증폭을 위하여 사용한 primer는 Table 1 에 제시하였 다. RT-PCR 반응액은 추출한 RNA 1 ul를 RT-PCR kit (iNvitrogen, $\mathrm{KOREA}$ )에 넣어 부피가 $20 \mathrm{ul}$ 가 되도록 한 후 1 회 $\left(42^{\circ} \mathrm{C} 45\right.$ 분, $94^{\circ} \mathrm{C} 5$ 분 $), 40$ 회 $\left(94^{\circ} \mathrm{C} 30\right.$ 초, $55^{\circ} \mathrm{C} 30$ 초, $72^{\circ} \mathrm{C}$ 40 초), 1 회 $\left(72^{\circ} \mathrm{C} 5\right.$ 분)를 Thermal cycler (C-1000 thermal cycler, BIO-RAD, USA)에서 수행하였다. 2차 PCR 반응액은 1st $\mathrm{PCR}$ 산물 $1 \mathrm{ul}$ 를 2차 PCR kit (BIONEER, KOREA)에 넣어 부피가 $20 \mathrm{ul}$ 가 되도록 한 후 1 회 $\left(94^{\circ} \mathrm{C} 5\right.$ 분 $), 40$ 회 $\left(94^{\circ} \mathrm{C} 30\right.$ 초, $55^{\circ} \mathrm{C} 30$ 초, $72^{\circ} \mathrm{C} 40$ 초 $), 1$ 회 $\left(72^{\circ} \mathrm{C} 5\right.$ 분 $)$ 를 Thermal cycler에서 수행하였다. PCR생성물 $(5 \mathrm{ul})$ 은 prestaining (SYBR safe, Invitrogen, USA)된 agarose gel (TaKaRa, Japan)에 100 bp

Table 1. Primers used for amplication of the VP1 region and sequencing primer

\begin{tabular}{ccl}
\hline Method & Primer & \multicolumn{1}{c}{ Sequence $\left(5^{\prime}-3^{\prime}\right)$} \\
\hline VP 1 & $224 \mathrm{~N}-1 F^{\mathrm{b}}$ & GCRATGTTRGGRACWCATGT \\
1 st PCR & $224 \mathrm{~N}-2 \mathrm{~F}$ & GCSATGTTRGGMACRCAYGT \\
& $224 \mathrm{~N}-14 \mathrm{R}^{\mathrm{c}}$ & GGRTTBGWKGANGTYTGCCA \\
\hline & $89 \mathrm{~N}-2 \mathrm{~F}$ & CCHGCDCTHACCGCWGTGGARACDGG \\
VP1 & $89 \mathrm{~N}-17 \mathrm{~F}$ & CCMATMCTHCAAGCHGCHGAGAYYGG \\
2nd PCR & $89 \mathrm{~N}-14 \mathrm{R}$ & GGRSCNCCDGGWGGYACAWACAT \\
& $89 \mathrm{~N}-19 \mathrm{R}$ & GGHGCVCCYGGYGGYACRTACAT \\
\hline
\end{tabular}

${ }^{\mathrm{a}}$ Virus protein, ${ }^{\mathrm{b}}$ Forward, ${ }^{\mathrm{c}}$ Reverse 
DNA ladder (TaKaRa, Japan)와 함께 loading 하고 30분간 전기영동(Advance, Japan)하여 Image analyzer (Geldoc XR image system, BIO-RAD, USA)로 $350 \mathrm{bp}$ band를 확인하였다.

\section{염기서열 분석}

$350 \mathrm{bp}$ 에서 증폭된 2차 PCR 산물은 염기서열분석을 위하 여 agarose gel에서 가능한 작게 원하는 DNA band를 잘라 $1.5 \mathrm{ml}$ tube로 옮긴 후 QIAquick gel Extraction kit (QIAgen, Germany)를 이용하여 정제하였다. 이 정제과정을 통해 회수 된 DNA를 주형으로하여 ABI PRISM Dye terminator (Perkin-Elmer Applied Biosustem, USA)를 사용하여 염기서 열 결정반응을 수행하였다. 염기서열 분석을 위한 primer는 엔테로바이러스 VP1 region RT-PCR에 사용된 것 중 VP1 2nd $\mathrm{PCR}$ 과 같다(Table 1). 확인된 염기서열은 SeqMan program (DNASTAR, Madison, WI)으로 align하고 Clustal W 방법으 로 Lasergene program을 이용하여 계통수를 작성하였다.

\section{결과 및 고찰}

\section{유행양상 분석}

엔테로바이러스 감염의심 환자 검체 2,743건을 세포배양하 여 160 건에서 세포병변 현상을 관찰하였다. 세포병변 현상은 $\mathrm{HEV}$ 에 감수성을 갖는 $\mathrm{RD}, \mathrm{BGM}, \mathrm{Vero}, \mathrm{Hep}-2$ cell에 검체를 접종하였으며 접종한 후 2주까지 관찰하여, $\mathrm{HEV}$ 에 의한 세포 의 원형화, 세포질의 수축, 세포의 파괴 등의 세포병변 현상이 관찰된 것을 양성으로 판정하였다(Fig. 1).

전처리가 끝난 검체에서 RNA를 분리하여 VP1 region RT-PCR한 결과 129 건의 검체에서 증폭산물인 $350 \mathrm{bp}$ band를 확인할 수 있었다(Fig. 2). 증폭된 PCR 산물들은 정제시킨 후 염기서열을 결정하였으며, 각각의 VP1 유전자에 대한 염기서 열을 이용하여 혈청형을 결정하였다.

총 2,743건의 검체 중 세포배양과 VP1 region RT-PCR을 이용한 시험 결과 240 건(8.7\%)에서 $\mathrm{HEV}$ 가 검출되었다. 연도 별로는 2007 년 검체 1,001 건에서 86 건(8.6\%)이 분리되었고, 2008년 979건 중 85건(8.7\%), 2009년 763건 중 69건(9.0\%)이

(A)

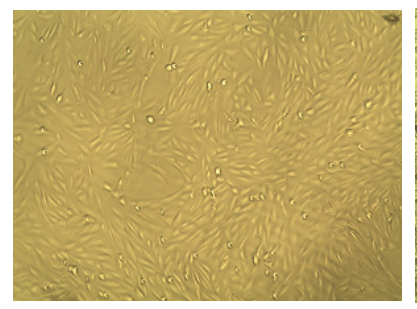

(B)

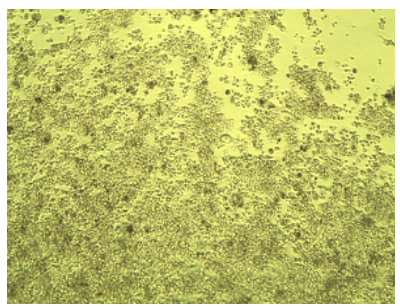

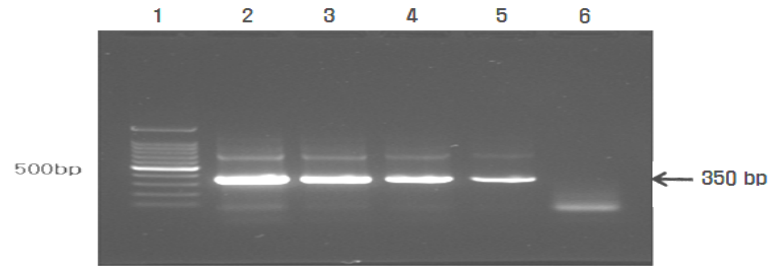

Fig. 2. Electrophoretic analysis of the 2nd PCR products after amplification of the VP1 region. Lane 1: $100 \mathrm{bp}$ DNA ladder, lanes 2-4: positive cases of VP1 RT-PCR, lane 5: positive control, lane 6: negative control.

분리되어 부산지역에서 매년 비슷한 수준으로 HEV가 유행하 고 있음을 알 수 있었다. 또한 5월부터 분리율이 증가하기 시 작해서 6월(15.5\%), 7월(15.8\%), 8월(15.3\%)에 높게 나타나 하 절기에 집중되어 나타난 것을 확인할 수 있었다(Fig. 3). 이전 부산지역에서 분리된 $\mathrm{HEV}$ 의 분석 결과를 보면 2005년엔 $13.3 \%$ 의 분리율을, 2006 년엔 $3.7 \%$ 의 분리율을 보이고 있다 [10]. 같은 시기에 충남지역에서 연구된 $\mathrm{HEV}$ 의 검출 결과는 2005년엔 $15.2 \%$ 의 분리율을[18], 2006년엔 9.6\%의 분리율을 보이는 것으로 나타났다[19]. 이로 볼 때 지역적으로 약간의 차이는 있으나, 지역마다 매년 $\mathrm{HEV}$ 가 꾸준히 유행하고 있음 을 알 수 있었다.

바이러스가 분리된 사례 중 성별이 확인되었던 226건 중 137건(57.1\%)이 남자였고, 여자에서는 89건(37.1\%)으로 나타 났다. 성별에 따른 바이러스 분리율의 차이가 보이고 있으나 이는 검사건수에서 남 - 녀 차이가 있었던 것으로 보이고 검사 건수 별 양성률은 남자 $9.5 \%$, 여자 $8.7 \%$ 로 성별에 따른 분리율 의 차이를 보기에는 어려울 것으로 사료 된다. 연령을 분석한 결과 1 세 이하( 1,274 건)검체가 전체(2,743건)검체의 $46.4 \%$ 를 차지하였다. 영유아의 바이러스성 수막염의 원인인 $\mathrm{HEV}$ 의 특 성상 연령이 증가함에 따라 분리율이 낮아지는 경향을 보였으 며, 대부분 10 세 이하의 연령에서 $\mathrm{HEV}$ 가 분리 되었다. 연령별 분리율은 2 4세군에서 $15.2 \%$ 로 가장 높았고, 5 9세군에서 $10.4 \%$ 로 다음으로 높게 나타났으며, 그 외 연령군에서는 비슷 한 분포를 나타내었다(Fig. 4).

분리된 240건 중 VP1 유전자에 대한 염기서열을 분석하여

Fig. 1. The cytopathic effect (CPE) of HEV on RD, BGM, Vero cells. (A) Vero; uninoculated, (B) RD; CPE+, C) BGM; CPE+, (D) Vero; CPE+ 


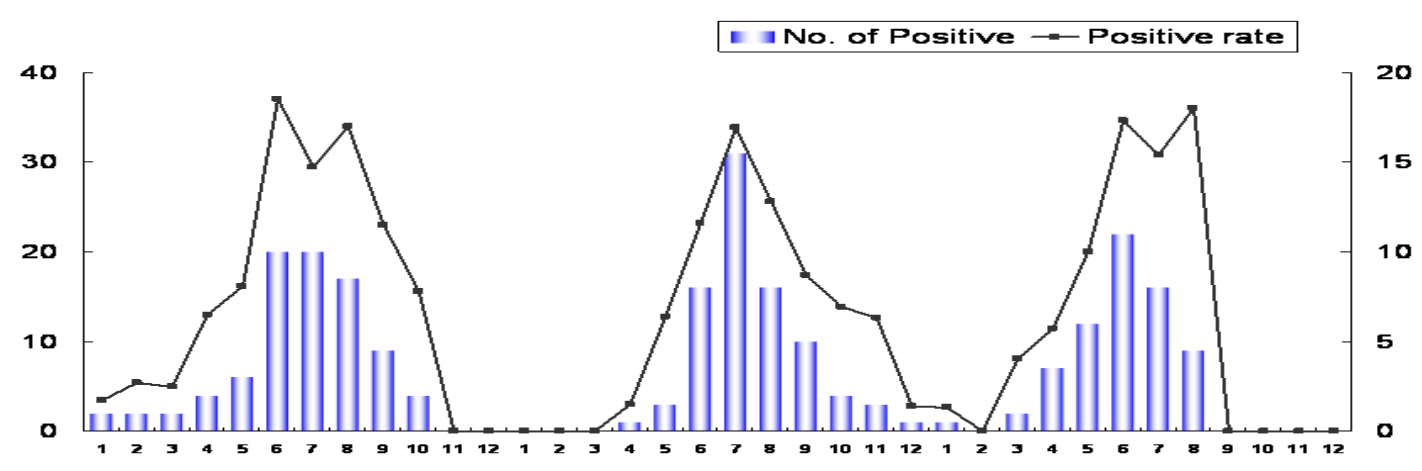

Fig. 3. Monthly distribution of the isolated HEV during 2007 2009 in Busan.

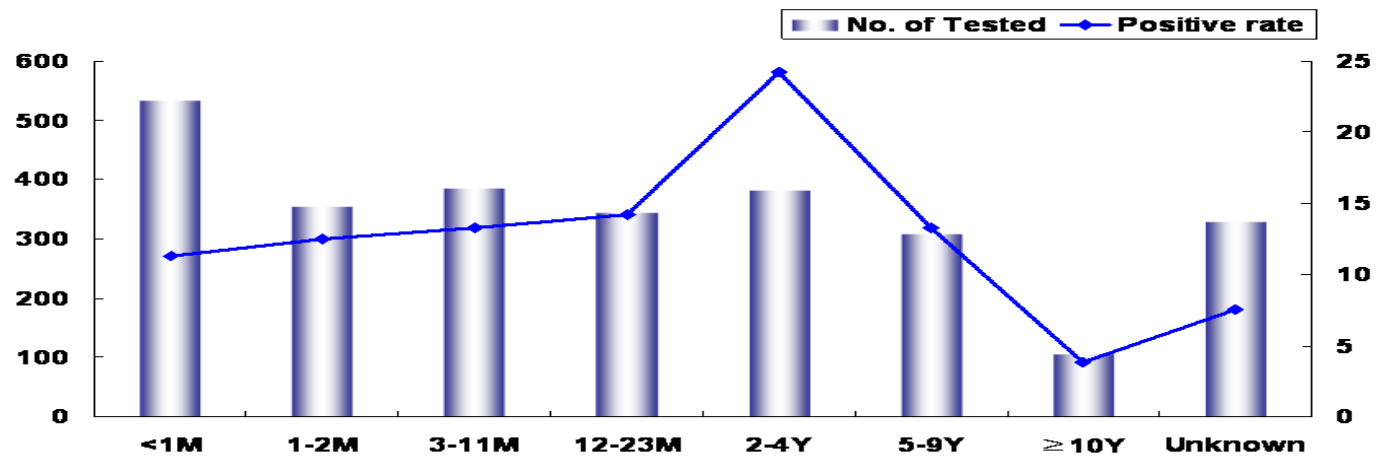

Fig. 4. Age distribution of children infected with HEV isolates during 2007 2009 in Busan.

혈청형을 확인한 결과 2007년은 분리된 86건 중 CV-B2 (23건), CV-A9 (20건)이 가장 많았으며, E-9 (8건), EV-71 (7건), CV-A2 (6건), CV-A10 (6건), CV-A5 (5건), CV-A6 (2건), CV-A24 (2 건), CV-A8 (1건), E-30 (1건), Untype (5건)의 순으로 나타났 다. 2008년은 분리된 85건 중 E-6 (37건), E-30 (18건)이 가장 많았으며, CV-B3 (14건), E-7 (5건), E-9 (3건), CV-A4 (3건), CV-B4 (2건), CV-A2 (1건), CV-A16 (1건), CV-B1 (1건)의 순으 로 나타났다. 2009년은 분리된 69건 중 CV-B1 (32건)이 가장 많았으며, 그 외에 E-11 (10건), CV-A4 (5건), CV-A2 (4건), CV-A16 (4건), CV-B3 (1건), E-3 (1건), E-6 (1건), E-25 (1건), Untype (10건)의 순으로 나타났다(Table 2).

\section{유전자형 연구}

240건의 분리주들에 대하여 VP1 region sequencing을 통한 분석 결과 HEV-A와 HEV-B 두 종류의 유전자형이 부산지역 에서 유행하였음을 확인할 수 있었다. HEV-A로 분류된 혈청 형은 6종(CV-A2, CV-A4, CV-A5, CV-A10, CV-A16, EV-71), 총 31건이었으며, HEV-B로 분류된 혈청형은 10 종(CV-A9, CV-B1, CV-B2, CV-B3, CV-B4, E-6, E-7, E-9, E-11, E-30), 총 41 건으로 나타나 각각의 상동성을 비교 분석 하였다.

HEV-A의 부산지역 분리주 31주를 이용하여 상동성 비교분 석을 실시한 결과 분리주 31주 사이에 $21.8 \sim 100 \%$ 의 상동성을
Table 2. Distribution of HEV isolated during 2007 2009 in Busan

\begin{tabular}{|c|c|c|c|c|c|}
\hline \multicolumn{2}{|c|}{ Enterovirus } & \multicolumn{3}{|c|}{ Year } & \multirow{2}{*}{ Subtotal } \\
\hline Group & Serotype & 2007 & 2008 & 2009 & \\
\hline \multirow{9}{*}{$\mathrm{CVA}^{\mathrm{a}}$} & CVA2 & 6 & 1 & 4 & 11 \\
\hline & CVA4 & & 3 & 5 & 8 \\
\hline & CVA5 & 5 & & & 5 \\
\hline & CVA6 & 2 & & & 2 \\
\hline & CVA8 & 1 & & & 1 \\
\hline & CVA9 & 20 & & & 20 \\
\hline & CVA10 & 6 & & & 6 \\
\hline & CVA16 & & 1 & 4 & 5 \\
\hline & CVA24 & 2 & & & 2 \\
\hline \multirow{4}{*}{$\mathrm{CVB}^{\mathrm{b}}$} & CVB1 & & 1 & 32 & 33 \\
\hline & CVB2 & 23 & & & 23 \\
\hline & CVB3 & & 14 & 1 & 15 \\
\hline & CVB4 & & 2 & & 2 \\
\hline \multirow{7}{*}{$\mathrm{ECV}^{\mathrm{c}}$} & ECV3 & & & 1 & 1 \\
\hline & ECV6 & 8 & 37 & 1 & 46 \\
\hline & ECV7 & & 5 & & 5 \\
\hline & ECV9 & & 3 & & 3 \\
\hline & ECV11 & & & 10 & 10 \\
\hline & ECV25 & & & 1 & 1 \\
\hline & ECV30 & 1 & 18 & & 17 \\
\hline Enterovirus & $\mathrm{EV}^{\mathrm{d}} 71$ & 7 & & & 7 \\
\hline \multicolumn{2}{|c|}{ Untype } & 5 & 0 & 10 & 15 \\
\hline \multicolumn{2}{|c|}{ Total } & 86 & 85 & 69 & 240 \\
\hline
\end{tabular}

${ }^{\mathrm{a}}$ Coxsackievirus A, ${ }^{\mathrm{b}}$ Coxsackievirus B, ${ }^{\mathrm{c}}$ Echovirus, ${ }^{\mathrm{d}}$ Enteroviruses 
보였으며, HEV-A 중 CV-A2 분리주 10주 사이에서 67.1 $100 \%$ 의 상동성을, $\mathrm{CV}-\mathrm{A} 4$ 분리주 8주 사이에서 $85.3 \sim 100 \%$ 의 상동성을, $\mathrm{CV}-\mathrm{A} 5$ 분리주 2주 사이에서 $83.2 \%$ 의 상동성을, $\mathrm{CV}-\mathrm{A} 10$ 분리주 2주 사이에서 $98.9 \%$ 의 상동성을, CV-A16 분 리주 5주 사이에서 95.8 100\%의 상동성을, 마지막으로 EV-71 분리주 3주 사이에서 99.0 99.3\%의 상동성을 보이는
것으로 확인되었다(Fig. 5).

HEV-B의 부산지역 분리주 41 주를 이용하여 상동성 비교분 석을 실시한 결과 분리주 41 주 사이에 $56.0 \sim 100 \%$ 의 상동성을 보였으며, HEV-B 중 CV-A9 분리주 2주 사이에서 $97.2 \%$ 의 상 동성을, CV-B1 분리주 5주 사이에서 $97.8 \sim 100 \%$ 의 상동성을, CV-B2 분리주 4 주 사이에서 $96.2 \sim 100 \%$ 의 상동성을, CV-B3

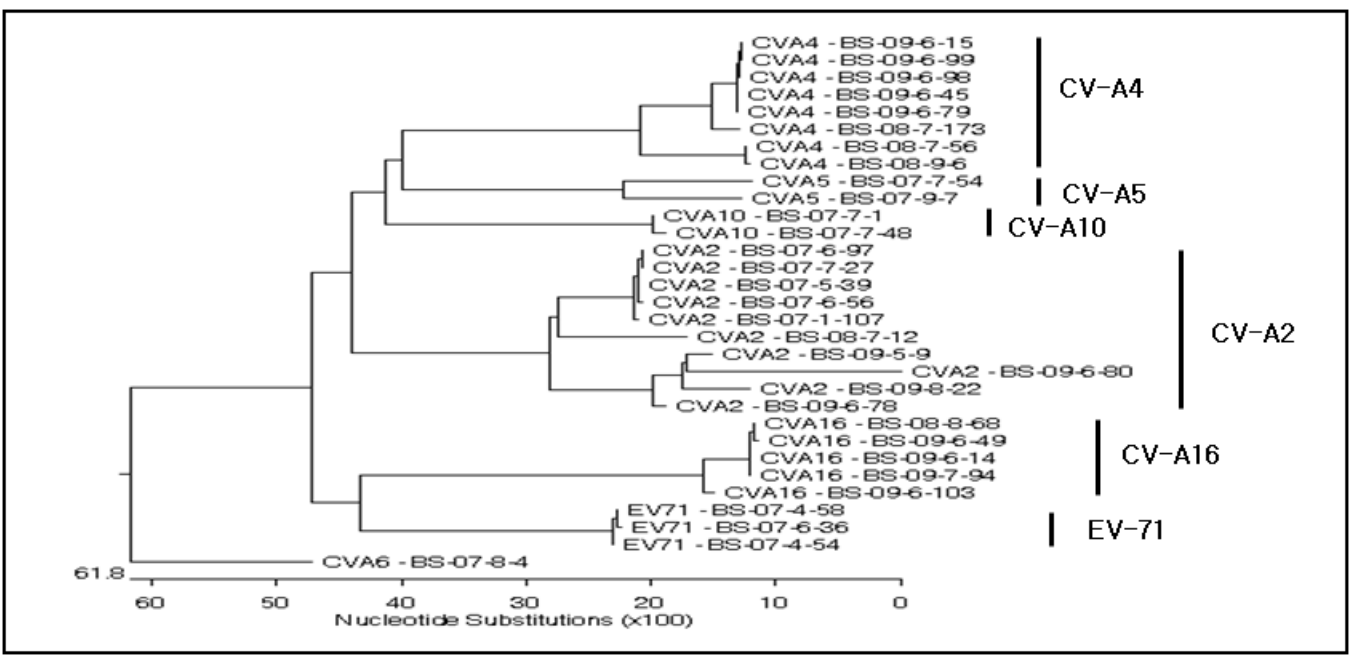

Fig. 5. Phylogenetic relationships in the VP1 region of HEV-A strains isolated from Busan region during 2007 2009. Phylogram was constructed by comparison of the partial sequences of the VP1 region. Nucleotide sequences encoding the VP1 were analysed by Clustal W method.

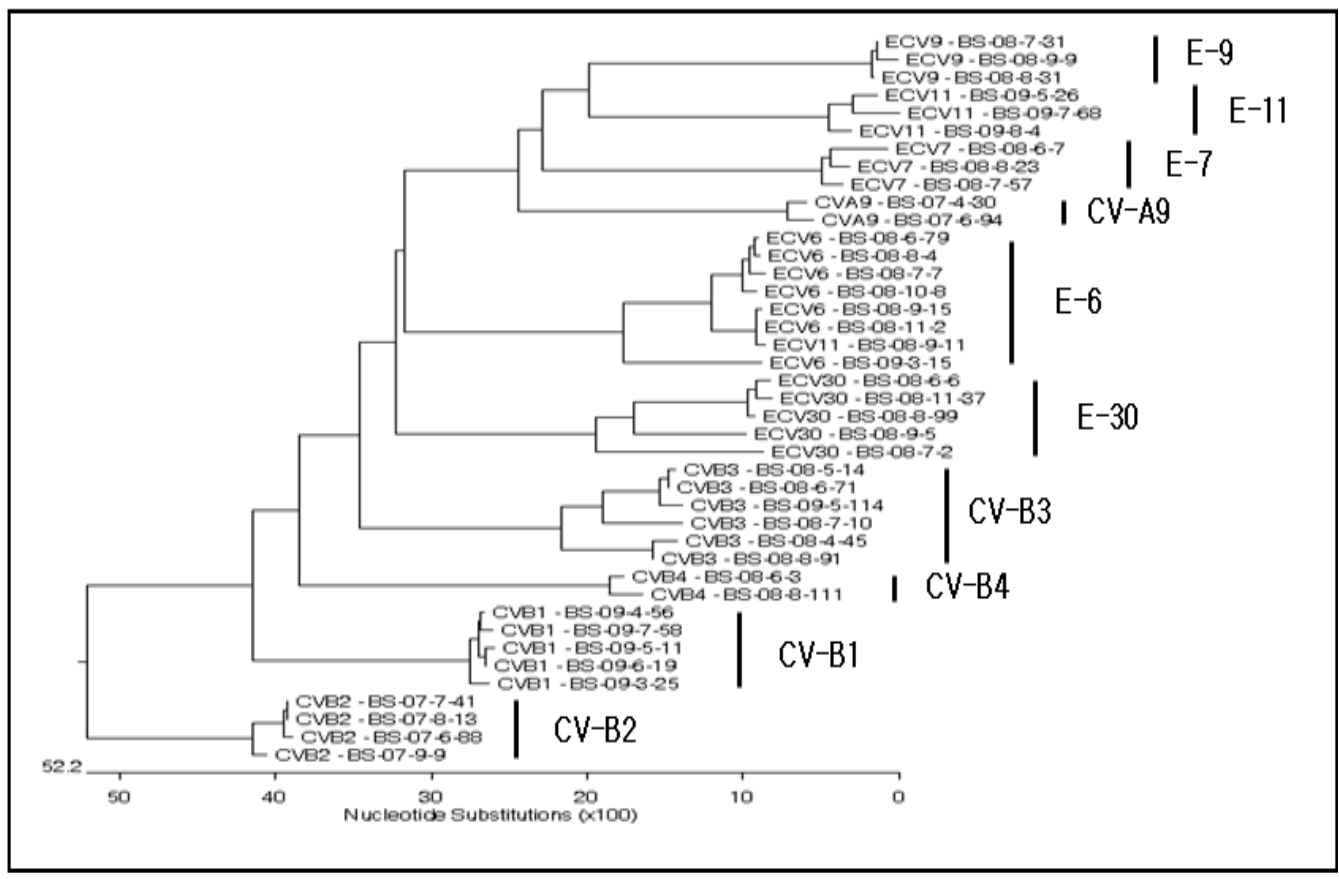

Fig. 6. Phylogenetic relationships in the VP1 region of HEV-B strains isolated from Busan region during 2007 2009. Phylogram was constructed by comparison of the partial sequences of the VP1 region. Nucleotide sequences encoding the VP1 were analysed by Clustal $\mathrm{W}$ method. 
분리주 6주 사이에서 85.0 99.7\%의 상동성을, CV-B4 분리주 2주 사이에서 $97.2 \%$ 의 상동성을, E-6 분리주 7 주 사이에서 83.9 98.8\% 의 상동성을, E-7 분리주 3주 사이에서 94.1 $96.0 \%$ 의 상동성을, E-9 분리주 3주 사이에서 $99.1 \sim 99.7 \%$ 의 상동성을, E-11 분리주 4주 사이에서 59.3 93.1\%의 상동성을, 마지막으로 ECV30 분리주 5주 사이에서 80.6 98.5\%의 상동 성을 보이는 것으로 확인되었다(Fig. 6).

2005년도에 충남지역 유행을 주도한 E-18의 경우 분리주들 간 $95.8 \% ~ 99.2 \%$ 의 상동성을 보였고, 동일한 혈청형이 같은 시기에 유행하였음에도 불구하고 $4.2 \%$ 의 다양성을 보였으며 [18], CV-B3의 경우 분리주들간 $80.5 \%$ 90.0\%의 상동성을 보 였다[17]. 또한 2006년도에 충남지역 유행을 주도한 E-5의 경 우 분리주들간 $97.7 \%$ 99.4\%의 상동성을 보였고, 외국의 원형 주들과의 상동성 비교에서는 $79.4 \% ~ 85.9 \%$ 의 수치를 보였다 [19]. 유전형간의 핵산염기서열 상동성 비교를 실시한 결과 서 로 같은 혈청형 간에도 상동성의 차이를 보이는 것은 $\mathrm{HEV}$ 가 한가닥의 RNA를 가지므로 돌연변이율이 매우 높다는 보고가 있다[2]. 본 연구를 통해서 최근 3년간 부산지역에 분리된 $\mathrm{HEV}$ 혈청형들 사이에 상동성의 차이를 보이는 결과를 확인 할 수 있었으며, 이를 볼 때 부산지역에서 유행하는 HEV 내에 상당한 정도의 유전자 변이가 있는 것을 확인할 수 있었다. 이번 연구에서 수행한 $\mathrm{HEV}$ 의 계통발생학적 관계에 대한 연구 는 향후 국내에서 수행될 $\mathrm{HEV}$ 진단 키트 개발 및 백신개발을 위한 기초 자료를 제공할 수 있을 것이며, 나아가 분자 유전학 적인 연구에 있어 한 단계 더 진보할 수 있는 계기가 될 수 있을 것으로 사료된다.

\section{References}

1. Andersson, P., K. Edman, and A. M. Lindberg. 2009. Molecular analysis of the echovirus 18 prototype : Evidence of interserotypic recombination with echovirus 9. Virus Res. 85, 71-83.

2. Choutet, P. and J. M. Besiner, 1994. Acute viral meningitis. Rev. Prat 44, 2172-2176.

3. Drake, J. W. 1993. Rates of spontaneous mutation among RNA viruses. Proc. Natl. Acad. Sciences 90, 4171-4175.

4. Egger, D., L. Pasamontes, M. Ostermayer, and K. Bienz. 1995. Reverse transcription multiplex PCR for differentiation between polio- and enteroviruses from clinical and environmental samples. J. Clin. Microbiol. 33, 1442-1447.

5. Formiga-Cruz, M., G. Tofino-Quesada, S. Bofill-Mass, D. N. Lees, K. Henshilwood, A. K. Allard, and et al. 2002. Distribution of human viral contamination in shellfish from different growing areas in Greece, Spain, Sweden and the United Kingdom. Applied and Environmental Microbiology 68, 5990-5998.

6. Ho, M. 2002. Enterovirus 71: the virus, its infections and outbreaks. J. Mocrobiol. Immunol. Infect. 33, 205-216.

7. Hyypia, T., T. Hovi, N. J. Knowles, and G. Stanway. 1997.
Classification of enteroviruses based on molecular and biological properties. J. Gen. Virol. 78, 1-11.

8. Lin, K. H., K. P. Hwang, G. M. Ke, C. F. Wang, L. Y. Ke, Y. T. Hsu, Y. C. Tung, P. Y. Chu, B. H. Chen, H. L. Chen, C. L. Kao, J. R. Wang, H. L. Eng, S. Y. Wang, L. C. Hsu, and H. Y. Chen. 2006. Evolution of EV71 genogroup in Taiwan from 1998 to 2005: an emerging of subgenogoup C4 of EV71. J. Med. Virol. 78, 254-262.

9. Melnick, J. L. 1996. Enteroviruses: poliovirus, coxsackieviruses, echoviruses, and newer enteroviruses. 3rd (eds.), pp. 655-712, In Fields, B. N., D. M. Knipe, P. M. Howley, R. M. Channock, J. L. Melnick, T. P. Monath, B. Roizman, S. E. Straus (eds.), Fields virology. Lippincott-Raven Publishers.

10. Na, Y. R. 2009. Isolation and genetic characterization of human enteroviruses in Busan pvovince. Ph. D. Thesis, Chonnam National University, Chonnam, Korea.

11. Nijhuis, M., N. Maarseveen, R. Schuurman, S. Verkuijlen, M. Vos, K. Hendriksen, and et al. 2002. Rapid and sensitive routione detection of all members of the genus Enterovirus in different clinical specimens by real-time PCR. J. Clin. Microbiol. 40, 3666-3670.

12. Nix, W. A., M. S. Oberste, and M. A. Pallansch. 2006. Sensitive, seminested PCR amplification of VP1 sequences for direct identification of all enterovirus serotypes from original clinical specimens. J. Clin. Microbiol. 44, 2698-2704.

13. Oberste, M. S., K. Maher, W. A. Nix, S. M. Michele, M. Uddin, D. Schnurr, S. Busaidy, C. Akoua-Koffi, and M. A. Pallansch. 2007. Molecular identification of 13 new enterovirus types, EV79-88, EV97, and EV100-101, members of the species Human enterovirus B. Virus Res. 128, 34-42.

14. Pallansch, M. A. and R. P. Roos. 2001. Enterovirus: Polioviruses, coxsackieviruses, echoviruses, and newer enteroviruses, 4th eds., pp. 691-775, In Knipe, D. M., P. M. Howley (eds.), Fields violory. Philadelphia, Pennsylvania: Lippincott-Raven Publishers.

15. Pallansch, M. A. and R. P. Roos. 2007. Enteroviruses: poliovirus, coxsackievirus, echoviruses, and newer enteroviruses. 5th eds., pp. 839-893, In Knipe, D. M., P. M. Howley, R. A. Lamb, M. A. Martin, B. Roizman, S. E. Straus (eds.), Fields Virology. Lippincott Williams \& Wilkins, Philadelphia.

16. Palmenberg, A. C. 1990. Proteolytic processing of picornaviral polyprotein. Annu. Rev. Microbiol. 44, 603-623.

17. Park, K. S., K. A. Baek, K. J. Kim, T. J. Mun, S. M. Park, J. D. Kim, W. S. Kim, N. S. Song, and C. K. In. 2008. Characterization of complete cenome of coxsackievirus B3 from patient with aseptic meningitis. Journal of CNIHE 18, 11-24.

18. Park, K. S., S. Y. Sung, J. D. Kim, N. S. Song, Y. T. Cha, Y. J. Jeong, J. K. Kim, T. J. Lee, and W. S. Seo. 2006. Laboratory Surveillance and Molecular Characterization for the enterovirus in Chung-Nam area. Journal of CNIHE 16, 11-25.

19. Park, K. S., S. Y. Sung, S. M. Park, J. D. Kim, N. S. Song, K. A. Baek, T. J. Lee, K. J. Kim, and C. K. In. 2007. Epidemiological analysis of enterovirus and phylogenetic stuey of the prevalent echovirus 5 in ChungNam area. 
Journal of CNIHE 17, 11-24.

20. Paula, A. S., D. Sabine, P. C. Divina, and S. Eckart. 2008. Identification of enterovirus serotypes by pyrosequencing using multiple sequencing primers. Journal of Virological Methods 148, 260-264.

21. Ravcaniello, V. R. 2001. Picornaviridae: The virus and their replication. In Fields Virology, pp. 685-722, 4th eds., In Knipe, D. M. and P. M. Howley (eds.), Lippincott Willians \& Wilkins.

22. Reimann, B. Y., R. Zell, and R. Kandolf. 1991. Mapping of a neutralizing antigenic site of a coxsackievirus B4 by construction of an antigenic chimera. J. Virol. 65, 3475-3480.

23. Rodgers, F. G. 1981. Concetration of viruses in faecal samples from patients with gastroenteritis. pp. 15-18, In
Goddard, M. and M. Bulter (eds.), Viruses and Wastewater Treatment. Pergamon Press, New York.

24. Shimizu, H., A. Utama, N. Onnimala, C. Li, Z. Li-Bi, M. Yu-Jie, Y. Pongsuwanna, and T. Miyamura. 2004. Molecular epidemiology of enterovirus 71 infection in the Western Pacific Region. Pediatr. Int. 46, 231-235.

25. Wyn-Jones, A. P. and J. Sellwoods. 2001. Enteric viruses in the aquatic environment. Journal of Applied Microbiology 1, 945-962.

26. Shieh, Y. C., C. I.Wong, J. A. Krantz, and F. C. Hsu. 2008. Detection of naturally occuring enteroviruses in waters using direct RT-PCR and integrated cell culture-RT-PCR. Journal of Virological Method 149, 184-189

\section{초록 : 부산지역에서 분리된 엔테로바이러스의 유행양상 분석 및 유전자형 연구}

김남호* · 민상기 · 박은희 · 박연경 · 권순목 · 진성현

(부산광역시 보건환경연구원 역학조사과)

부산지역에서 2007년부터 2009년까지 3년 동안 임상적으로 $\mathrm{HEV}$ 의심 환자 검체 총 2,743건(대변 1,503건, 뇌 척수액 1,213 건, 인후도찰물 27 건)의 검체 중 240 건(8.7\%)에서 $\mathrm{HEV}$ 가 검출되었다. 연도별로는 2007 년에는 $\mathrm{HEV}$ 감염의심 환자 검체 1,001 건에서 86 건(8.6\%)에서 $\mathrm{HEV}$ 가 분리되었고, 2008년의 경우 979건 중 85건(8.7\%), 2009년 763 건 중 69 건 $(9.0 \%)$ 이 분리되었다. 본 연구에 사용된 검체 2,743 건 중 1,315 건이 6 월부터 9 월까지 4 개월간 의뢰되 어 전체 의뢰건수의 $48.0 \%$ 를 차지하였다. HEV는 5월부터 분리율이 증가하기 시작해서 6월(15.5\%), 7월(15.8\%), 8월(15.3\%)에 높게 나타나 HEV 분리가 하절기에 집중되어 나타난 것을 확인할 수 있었다. 검사건수 별 양성률은 남자 $9.5 \%$, 여자 $8.7 \%$ 로 성별에 따른 분리율의 차이를 찾기는 어려웠으며, 대부분 10 세 이하의 연령에서 바이러 스가 분리되었다. 분리된 $\mathrm{HEV}$ 분리주들에 대하여 VP1 region sequencing을 통하여 HEV의 유전형을 확인하여 HEV-A와 HEV-B 두 종류의 유전자형이 부산지역에서 유행하였음을 확인하였다. HEV-A의 부산지역 분리주 31 주를 이용하여 상동성 비교분석을 실시한 결과 분리주 31 주 사이에 $21.8 \sim 100 \%$ 의 상동성을 보였으며, HEV-B의 부산지역 분리주 41 주를 이용하여 상동성 비교분석을 실시한 결과 분리주 41 주 사이에 $56.0 \sim 100 \%$ 의 상동성 보 여 최근 3년간 부산지역에 분리된 $\mathrm{HEV}$ 혈청형들 사이에 상동성의 차이를 보이는 결과를 확인 할 수 있었으며, 이를 볼 때 부산지역에서 유행하는 $\mathrm{HEV}$ 내에 상당한 정도의 유전자 변이를 추정해 볼 수 있었다. 